\title{
РУЧНА ОБРОБКА МЕДИЧНИХ ЗОБРАЖЕНЬ ЛІКАРЕМ- ДІАГНОСТОМ У СИСТЕМІ РОЗПІЗНАВАННЯ ТОМОГРАФІЧНИХ І РЕНТГЕНІВСЬКИХ ЗНІМКІВ ДЛЯ ПОШУКУ І ЛОКАЛІЗАЦЇ̈ ПАТОЛОГІЙ
}

\section{Поляченко А. I.}

аспірант Київський національний університет імені Тараса Шевченка

Copyright (C) 2018 by author and the journal “Automation technologies and business - processes. This work is licensed under the Creative Commons Attribution International License (CC BY). http://creativecommons.org/licanses/by/4.0

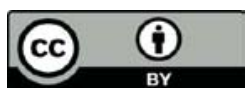

ONAFT

Open Access

DOI:

Анотація: У статті запропоновано та побудовано систему розпізнавання томографічних $і$ рентгенівських знімків для пошуку і локалізації патологій. Дана система включає блоки: введення інформації про пацієнта, обробки медичних зображень, для встановлення висновку, для класифікації виявлених патологій, базу даних, підготовки звіту. У запропонованій системі початковим етапом є отримання томографічних чи рентгенівських знімків, які, далі, поступають до блоків введення інформації про пацієнта і обробки медичних зображень. Інформація про пацієнта в результаті введення потрапляе до бази даних разом із томографічними чи рентгенівськими знімками. У пропонуємій системі розпізнавання томографічних і рентгенівських знімків для пошуку і локалізації патологій існує можливість для лікаря-діагноста самому виділяти підозрілу з його точки зору область і надалі обробити тільки иңю область або за допомогою існуючих загорткових нейронних мереж виділити області патологій-новоутворень, або вибрати конкретні алгоритми обробки медичних зображень.

Abstract: The article proposed and built a tomographic and X-ray recognition system for the search and localization of pathologies. This system includes blocks: patient information input, medical image processing, to establish a conclusion, to classify the pathologies identified, a database and a report. In the proposed system, the initial step is to obtain tomographic or $X$-ray images, which are then transferred to the patient information and medical image processing units. Information about the patient as a result of the introduction enters the database along with tomographic or X-ray images. In the proposed system of recognition of tomographic and X-ray images for the search and localization of pathologies, there is an opportunity for the diagnostician to independently isolate a region that is suspicious from his point of view and subsequently process only this area, including using convolutional neural networks to highlight areas of pathologies, neoplasms, or choose specific algorithms for processing medical images.

Ключові слова: ручна обробка, система розпізнавання, томографічні і рентгенівські знімки, пошук і локалізація патологій, лікар-діагност.

Key words: manual processing, recognition system, tomography and X-rays, search and localization of pathologies, diagnostician.

Постановка проблеми. При використанні комп'ютерної та магнітно-резонансної томографії (КТ та МРТ відповідно), найважливішою із задач, що постає перед лікарями, є визначення точних меж пухлин та інших аномальних утворень у тканинах організму людини [1]. Результатом обстеження при КТ і МРТ є серія знімків, що відповідають обраним площинам сканування. На основі отриманих знімків лікар візуально визначає наявність аномальних утворень та їх межі. Проблема полягає у тому, що наявність пухлин досить просто визначити візуально у силу їх характерних структурних особливостей, у той час як визначення точних меж між здоровими та ураженими тканинами $є$ дуже складною задачею, яку практично неможливо вирішити без виконання додаткових замірів та розрахунків [1]. Складність цієї задачі є наслідком того, що здорові та уражені тканини на знімках КТ та МРТ можуть виглядати практично однаково, у сенсі, наприклад, кольору відповідних областей, що, у свою чергу, унеможливлює використання методів візуального аналізу зображення для виявлення меж між вказаними областями [1, 2]. Тому 
виникає необхідність у побудові системи розпізнавання томографічних і рентгенівських знімків для пошуку і локалізації патологій.

Аналіз останніх досліджень і публікацій. Під час аналізу конкретного медичного зображення виникає необхідність вибору алгоритму, найбільш підходящого для його сегментації $[1,3,4]$. Фактично таке завдання стоїть, перед розробниками програмних засобів для МРТ-обладнання, а не перед лікарями-клініцистами, які використовують методи променевої діагностики. При виборі алгоритму доводиться враховувати як властивості конкретного медичного зображення, так і особливості певного алгоритму сегментації [1, 5]. У роботі [9] розроблено програмне забезпечення для вирішення основних завдань інформаційної підсистеми: завдань передачі інформації між підсистемами дослідження і діагностики внутрішньочерепних новоутворень, а також реєстрація пацієнта, перегляд і редагування його даних.

У той же час практично повністю відсутня автоматизована обробка розпізнавання томографічних і рентгенівських знімків для пошуку і локалізації патологій. Тому, даний напрям дослідження, на сьогодні, є актуальним.

Мета статті. У даній статті необхідно розробити систему розпізнавання томографічних і рентгенівських знімків для пошуку і локалізації патологій та розглянути принципи ручної обробки медичних зображень лікарем-діагностом.

Основні результати дослідження. Для пошуку і локалізації аномалій на томографічних і рентгенівських знімках пропонується система, яка буде складатися з наступних блоків (функціональна структура пропонуємої системи приведена на рис. 1):

- блок введення інформації про пацієнта;

- блок обробки медичних зображень, що включає:

- згорткову нейронну мережу (ЗНМ) для класифікації томографічних і рентгенівських знімків;

- ЗНМ для визначення залежностей значень просторового фактора $W z$ від стандартизованих $z$-значень і 3 наступним розрахунком коефіцієнту загальної просторової автокореляції;

- ЗНМ для сегментації томографічних і рентгенівських знімків;

- підсистему ручної обробки медичних зображень, що представлена лікарем-діагностом;

- блок для встановлення висновку, що включає нейронну мережу (НM), призначену для порівняння отриманих результатів;

- блок для класифікації виявлених патологій, що включає НМ;

- базу даних, як вже існуючих знімків, так і нових, у т.ч. з результатом оброблення;

- блок підготовки звіту.

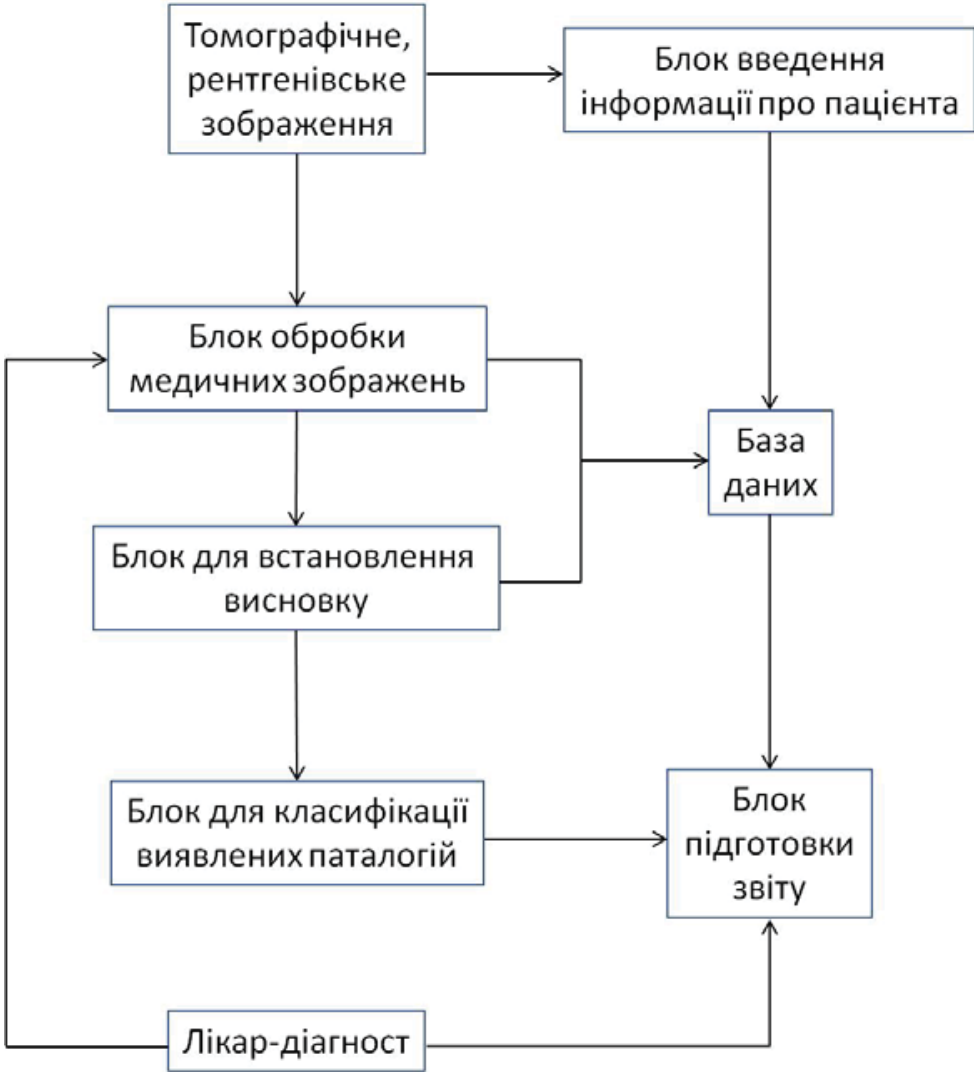

Рис. 1 - Загальний вигляд функціональної структури пропонусмої системи розпізнавання томографічних і рентгенівських знімків для пошуку і локалізації патологій 
http://www.atbp.onaft.edu.ua/

У приведеній функціональній структурі пропонуємої системи (рис. 1) початковим етапом є отримання томографічних чи рентгенівських знімків, які, далі, поступають до блоків введення інформації про пацієнта і обробки медичних зображень. Інформація про пацієнта в результаті введення потрапляє до бази даних разом із томографічними чи рентгенівськими знімками.

Блок обробки медичних зображень пропонуємої системи включає 4 підсистеми, які охоплюють автоматичну обробку томографічних чи рентгенівських знімків, а також обробку в ручному режимі лікарем-діагностом. У даній статті розглянуто принципи ручної обробки медичних зображень лікарем-діагностом за допомогою ЗНМ.

У пропонуємій системі розпізнавання томографічних і рентгенівських знімків для пошуку і локалізації патологій існує можливість для лікаря-діагноста самому виділяти підозрілу з його точки зору область і надалі обробити тільки цю область або за допомогою існуючих ЗНМ виділити області патологій-новоутворень, або вибрати конкретні алгоритми обробки медичних зображень.

Приклад ручної обробки медичних зображень лікарем-діагностом наведено на рис. 3.
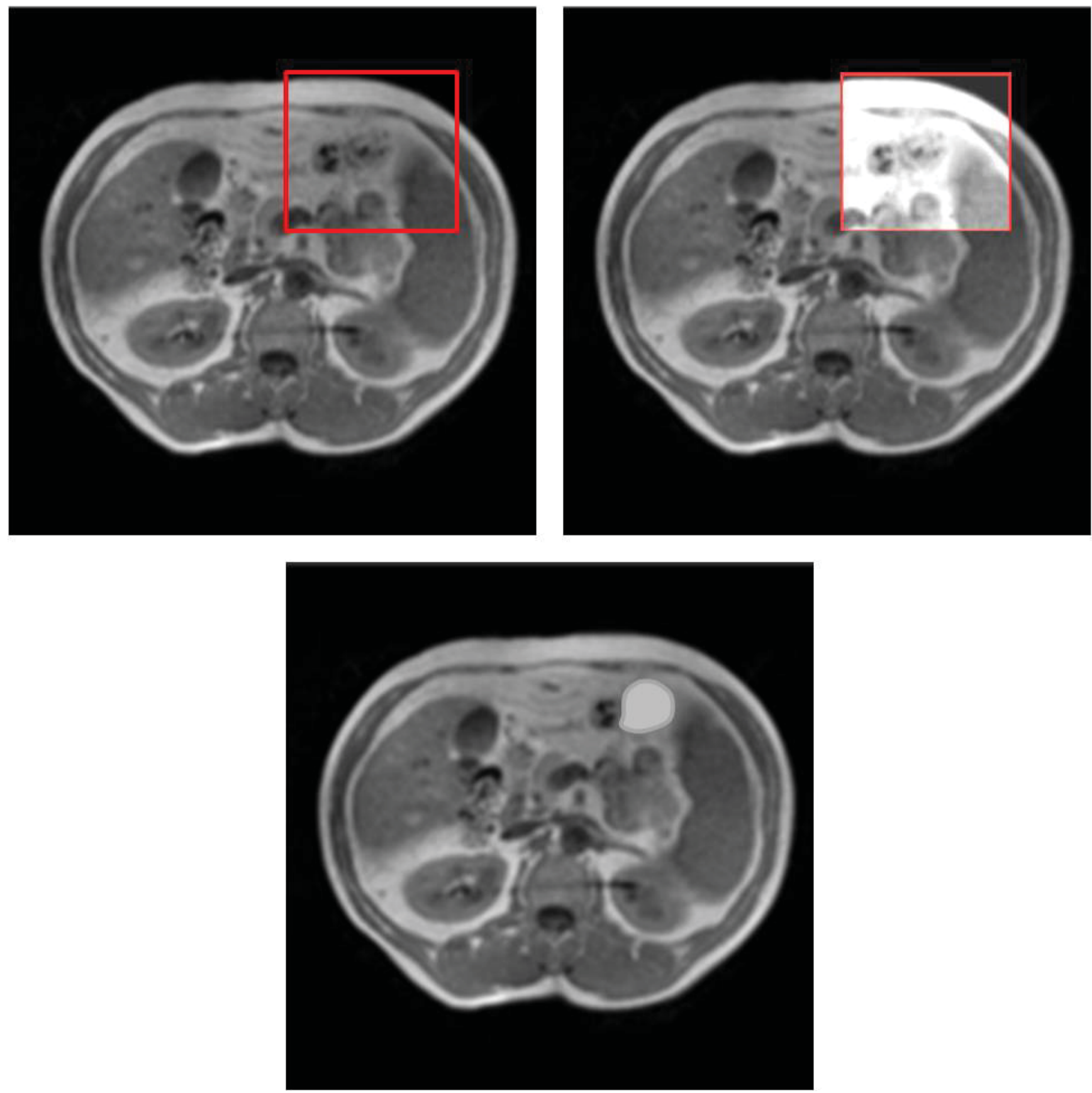

Рис. 3 - Приклад ручної обробки медичних зображень лікарем-діагностом (приведено по порядку: вихідний МРТ знімок, виділення області патології, сегментація за допомогою ЗНМ) 
Висновки та пропозиції. У статті запропоновано та побудовано систему розпізнавання томографічних i рентгенівських знімків для пошуку і локалізації патологій. Дана система включає блоки: введення інформації про пацієнта, обробки медичних зображень, для встановлення висновку, для класифікації виявлених патологій, базу даних, підготовки звіту. У запропонованій системі початковим етапом є отримання томографічних чи рентгенівських знімків, які, далі, поступають до блоків введення інформації про пацієнта і обробки медичних зображень. Інформація про пацієнта в результаті введення потрапляє до бази даних разом із томографічними чи рентгенівськими знімками. Блок обробки медичних зображень включає 4 підсистеми, які охоплюють автоматичну обробку томографічних чи рентгенівських знімків, а також обробку в ручному режимі лікарем-діагностом. У пропонуємій системі розпізнавання томографічних і рентгенівських знімків для пошуку і локалізації патологій існує можливість для лікаря-діагноста самому виділяти підозрілу з його точки зору область і надалі обробити тільки цю область або за допомогою існуючих ЗНМ виділити області патологій-новоутворень, або вибрати конкретні алгоритми обробки медичних зображень.

На основі розробленої системи розпізнавання томографічних і рентгенівських знімків для пошуку і локалізації патологій можна надати висновок про хворобу автоматично, або на основі суджень лікаря-діагноста.

\section{Список використаних джерел}

[1] Поляченко А.І. Можливості методів пошуку та локалізації аномалій у томографічних та рентгенівських знімках для підвищення точності встановлення діагнозу / А.І. Поляченко // Наукові нотатки. - 2018. - Вип. 64. - С. 159165.

[2] Поляченко А.І. Пошук контурів областей із певною патологічною структурою на МРТ знімках / А.І. Поляченко // Науковий журнал «Комп’ютерно-інтегровані технології: освіта, наука, виробництво». - Луцьк, 2019. - Випуск № 34. - С. 96-106.

[3] Anam M. An Efficient Brain Tumor Detection Algorithm Using Watershed \& Thresholding Based Segmentation / M. Anam, J. Ah, F. Tehseen // Image, Graphics and Signal Processing. - 2012. - Vol. 10. -Pp. 34-39.

[4] Logeswari T. An improved implementation of brain tumor detection using segmentation based on hierarchical self organizing map / T. Logeswari, M. Kaman // International Journal of Computer Theory and Engineering. - 2010. - Vol. 2, no. 4, pp. 1793-8201.

[5] Marr D. Proceedings of the Royal Society of London / D. Marr, E. Hildreth // Series B, Biological Sciences. - Vol. 207, no. 1167. - Pp. 187-217.

[6] Кирсанова А.В. Автоматизированная система диагностики новообразований головного мозга по магнитнорезонансным изображениям: Дис. канд. техн. наук: 05.11.17: Санкт-Петербург, 2004. - 148 с.

\section{References}

[1] Polyachenko A.I. Mozhlivosti metodiv poshuku ta lokalizaciï anomalij u tomografichnih ta rentgenivskih znimkah dlya pidvishchennya tochnosti vstanovlennya diagnozu. Naukovi notatki. Vip. 64. P. 159-165, 2018.

[2] Polyachenko A.I. Poshuk konturiv oblastej iz pevnoyu patologichnoyu strukturoyu na MRT znimkah. Naukovij zhurnal «Kompyuterno-integrovani tekhnologiï: osvita, nauka, virobnictvo». - Luck. Vipusk № 34. P. 96-106, 2019.

[3] M. Anam, J. Ah, F. Tehseen Efficient Brain Tumor Detection Algorithm Using Watershed \& Thresholding Based Segmentation. Image, Graphics and Signal Processing. Vol. 10. Pp. 34-39, 2012.

[4] T. Logeswari and M. Kaman, An improved implementation of brain tumor detection using segmentation based on hierarchical self organizing map. International Journal of Computer Theory and Engineering. Vol. 2, no. 4, pp. 17938201, 2010.

[5] D. Marr and E. Hildreth, Proceedings of the Royal Society of London. Series B, Biological Sciences. - Vol. 207, no. 1167. Pp. 187-217.

[6] Kirsanova A.V. Avtomatizirovannaya sistema diagnostiki novoobrazovanij golovnogo mozga po magnitnorezonansnym izobrazheniyam/ Dis. kand. tekhn. nauk: 05.11.17// Sankt-Peterburg. P. 148, 2004. 